\title{
The Effectiveness and Students' Perceptions on Learning Tenses Through Mind Mapping Technique on Elementary Level at an Education and Training Institute in Indonesia
}

\author{
Nur Alifah Annisa Jumrah ${ }^{*}$, Mirah Azizah1 \\ 1 Hasanuddin University, Makassar, Indonesia \\ ${ }^{*}$ Correspondence: alifahann@gmai.com
}

\begin{abstract}
Numerous studies had conducted the use of mind mapping as a technique in teaching and learning English, but relatively few of these studies focused on the effectiveness and students' perceptions of mind mapping technique in learning tenses on elementary level in a non-formal education institution. This study aimed to investigate the effectiveness of mind mapping technique in learning present tenses and students' perceptions toward this technique on elementary level students of the English program. 30 students of the English program on elementary level at Aliah Education and Training Institute Makassar took part in the study. Data were collected through pre-test, posttest, observation, questionnaire, and interview and thus used to analyze the results quantitatively and qualitatively using preliminary studies, general mean scores, and percentages of students'improvement score. Results of the study showed that the students were really enthusiastic to learn with this technique and the atmosphere of the classroom was more enjoyable. In addition, the students' ability in using tenses was improved after implementing this technique. In the pre-test, the general mean score of the students was 42.33 and classified as Very Poor. While, the general mean score of the students was 78.92 and classified as Good in the post-test. The students" improvement score was increased up to $86.44 \%$. It revealed that mind mapping technique is effective in learning tenses. However, it is suggested that further studies can be conducted with larger data to make it more accurate and applicable.
\end{abstract}

\section{ARTICLE HISTORY}

Published March $27^{\text {th }} 2021$

Check for updates

\section{KEYWORDS}

Effectiveness, Perceptions, Student, Tenses, Mind Mapping Technique

\section{ARTICLE LICENCE}

(C) 2021 Universitas Hasanuddin Under the license CC BY-SA 4.0

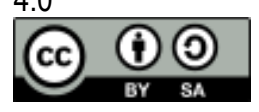

\section{Introduction}

English as an international language has become the most widely studied in the world. The fast growth of English has made this subject compulsory in educational settings for students in all countries, including Indonesia. Regarding this issue, the government has provided a regulation about English as the main foreign language that is necessary to be taught and studied in formal education (Rahman, 2018.; Aswad et al., 2019). In addition, English is also one of the important subjects tested as a measurement standard in the National Examination. However, it is still incomplete if it is only taught in formal education. Students should also increase their English skills in informal education (Junaidi, et al., 2020), for example in the English courses.

A lot of problems and difficulties are faced by the students in learning English which can be influenced by several factors (Rski, et al., 2018). The first factor is lack of understanding on the benefit of mastering English language. Secondly, the factor is about the implementation of teaching and learning process. Then, the third factor is learning technique used for the students. In the learning process, the last factor is learning technique, remains important to help students, especially in learning English as a foreign language. While, one of the problems in learning English is tenses. The English teachers should implement appropriate teaching strategy (Rahman, 2017) for the students to help them understand tenses easier. Brown (2001) and Junaidi (2020) define technique as a particular method used to obtain a specific goal. Commonly, students involve noting activities in learning process, including in learning English. However, this noting technique is not really effective for the students in memorizing learning materials. It is because the involvement of motor activity, such as 
writing, drawing, and seeing the images, colors, and diagrams are the learning activities that can increase memories for more than thirty percent (Olivia, 2013; Nahliah \& Rahman, 2018).

Based on the explanation above, the appropriate technique to be implemented is mind mapping technique. This technique is decided to improve students' ability in learning tenses. Buzan (2006) stated that mind mapping helps students study, arrange, and save wanted information as many as possible and naturally group it. Windura (2013) also states that mind mapping provides many benefits for students, such as improving creativity and helping concentrated in learning, thinking, and planning daily activities. According to Michalko in Priyasudiarja \& Purwaningsih (2014), "the use of mind mapping can help us to focus on one subject." Mind mapping technique depends on our creativity in making illustrations or images that want to be showed in representing the topic or subject. We have to use illustrations or images and colors as many as possible. By those facts, the students can work effectively because it will fulfill their needs for learning technique in gaining English knowledge, especially in learning tenses. This learning technique is useful for students because they can be more active in thinking and moving. Thus, it is believed that mind mapping technique can be used in learning tenses to represent the ideas of tenses and summarize the main ideas of tenses optimally. In addition, it also allows the students to be more active and creative in the classroom which will eventually lead them indirectly in understanding and memorizing tenses easier and accurately in a more efficient way.

The previous studies showed a variety of perspectives and approaches in the use of mind mapping techniques in teaching and learning English. However, there are limited studies concerned on the effectiveness and students' perceptions of mind mapping technique in learning tenses on an elementary level in a non-formal education institution. This study was conducted to analyze the effectiveness of mind mapping technique towards improving elementary-level students in mastering tenses, especially for several types of present tenses, and their perceptions towards the use of this technique. This study is expected to improve the strategy of English teachers in teaching tenses, develop educational tools for teaching and learning tenses with mind mapping technique, create a good atmosphere for interesting learning process, and overcome students' difficulties and problems in understanding tenses.

The grammatical form usually has a relation with tenses. Generally, tenses are defined as the time of the action or states, which can be seen in the verb form. Three types of tenses in English are Present Tense, Past Tense, and Future Tense. Wishon and Burks (1980) defined tenses as follows:

Tenses means time. However, it should be pointed out that time in the relation to action is a concept that exists in the mind of speaker, reader, or listener. Tense, in actual usage, refers consistently only to grammatical forms. Often tense and time do not correspond at all. Verbs in the present tense, for example, can indicate future tense.

It can be concluded that tenses plays a crucial role in English because tenses are the form that have many varieties in indicating time or period when the action takes place in past, present, or future.

Windura (2013) stated that mind mapping is the learning and thinking system that reflects visually to what is happening on learning and thinking. Mind mapping uses the visualization ability. It uses the color combination, pictures, and symbols. The pictures, color combination, and symbol help the students to understand the tenses knowledge and also create a good atmosphere in learning tenses because the students enjoy the process and attract visually which eventually help the students to memorize and understand the information. According to Olivia (2013), some components of mind mapping are pictures, association, colors, and keywords. Firstly, people tend to be more interested in pictures because they are easier to capture pictures than words. It is also because pictures help to reduce the words to be memorized. Secondly, using arrows, lines, and boxes can help the students make associations towards the information, which can be benefited from understanding and memorizing the information. Thirdly, color can increase the memory up to 50 percent. Lastly, keywords are the specific words that are important to remember and can make learning time more efficient up to 80 percent. In addition, several advantages of implementing mind mapping technique in learning. Those are: 1) helping to concentrate, 2) improving the visual intelligent and observation skill, 3) improving creativity, 4) improving thinking and independence, 5) making better notes and summary of lesson, 6) stimulating the expression of thinking, and 7) improving the initiative ability and curiousity (Olivia, 2013).

\section{Methodology}

This study's participants were thirty students of English program in the elementary level at Aliah Education and Training Institute Makassar. It was selected using total sampling method in which all the population in a classroom was involved as the samples for the representative results. This study's dependent variables are mind mapping technique and learning tenses, while the independent variables are the effectiveness and students' perceptions. 
This study employed mixed methods which involved quantitative and qualitative approaches. The techniques for data collection were used pre-test, post-test, observation, questionnaire, and interview. Firstly, the pre-test was conducted before implementing mind mapping technique as the treatment to get prior description of students' ability about tenses, consisting of 40 items about Simple Present Tense, Present Continuous Tense, Present Perfect, and Present Perfect Continuous Tense. Then, the treatment was given by implementing mind mapping technique in various types of Present Tense for three months with one and half hours duration of study. The learning process was observed while giving the treatment in the class to find out the situation of the students' class and responses. After three months of treatment, the participants were assessed for the post-test with same set of questions in the pre-test. The questionnaires were also administered to the participants to investigate students' perceptions on mind mapping technique and students' score improvement in teaching and learning process, which covered 20 questions. Finally, the interview was conducted with 6 questions to obtain more information related to students' perceptions of mind mapping techniques in learning tenses. Numerous studies have been used mixed methods, particularly for case study. The strengths of using this method are comparison of quantitative and qualitative data, explanation of quantitative data with qualitative data, and better measurement instruments. However, this method also has several weaknesses, such as the need for extensive data collection, time-intensive nature for quantitative and qualitative data analyses, and the complexity of both quantitative and qualitative research design to be familiar by the researcher.

\section{Findings And Discussion}

This study was conducted from September to December for three times a week during one and half hours at Aliah Education and Training Institute Makassar. These findings covered the effectiveness of mind mapping technique and students' perceptions of the mind mapping technique at Aliah Education and Training Institute Makassar. It can be seen from students' achievement on test result, both the pre-test and post-test.

\subsection{The Effect of Mind Mapping Technique on Students' Tenses:}

Table 1. Pre-Test Result

\begin{tabular}{ccc}
\hline Score & Frequency & Total \\
\hline 17.5 & 1 & 17.5 \\
\hline 20 & 2 & 40 \\
\hline 22.5 & 3 & 67.5 \\
\hline 27.5 & 3 & 82.5 \\
\hline 30 & 2 & 60 \\
\hline 32.5 & 1 & 32.5 \\
\hline 37.5 & 1 & 37.5 \\
\hline 40 & 1 & 40 \\
\hline 42.5 & 1 & 42.5 \\
\hline 45 & 2 & 90 \\
\hline 50 & 4 & 200 \\
\hline 52.5 & 2 & 105 \\
\hline 55 & 1 & 55 \\
\hline 60 & 4 & 240 \\
\hline 80 & 2 & 160 \\
\hline Total & 30 & 1270 \\
\hline
\end{tabular}

One student got 17.5, two students got 20, three students got 22.5, three students got 27.5 , two students got 30 , one student got 32.5 , one student got 37.5 , one student got 40 , one student got 42.5 , two students got 45 , four students got 50 , two students got 52.5 , one student got 55 , four students got 60 , and two students got 80 . The general mean score of the students was $M=1270 / 30=42.33$ which classified as Very Poor.

Table 2. Post-Test Result

\begin{tabular}{ccc}
\hline Score & Frequency & Total \\
\hline 50 & 3 & 150 \\
\hline 60 & 1 & 60 \\
\hline 62.5 & 3 & 187.5 \\
\hline 70 & 1 & 70 \\
\hline
\end{tabular}




\begin{tabular}{ccc}
\hline 72.5 & 2 & 145 \\
\hline 75 & 2 & 150 \\
\hline 80 & 2 & 160 \\
\hline 85 & 3 & 255 \\
\hline 87.5 & 4 & 350 \\
\hline 90 & 3 & 270 \\
\hline 92.5 & 2 & 185 \\
\hline 95 & 2 & 190 \\
\hline 97.5 & 2 & 195 \\
\hline Total & 30 & 2367.5
\end{tabular}

Three students got 50 , one student got 60 , three students got 62.5 , one student got 70 , two students got 72.5 , two students got 75 , two students got 80 , three students got 85 , four students got 87.5 , three students got 90 , two students got 92.5 , two students got 95 , and two students got 97.5 . The general mean score of the student was $M=2367.5 / 30=$ 78.92 which classified as Good.

There was a significant result from pretest-posttest data, which can be measured on the students' percentage of improvement scores. It was calculated with formula: $P=y 1-y / y \times 100 \%$ which resulted $86.44 \%$. It showed that the score had improved $86.44 \%$ from pre-test score after using mind mapping technique. In addition, there was also students' achievement on their learning attitude. It was found that the students become more focused in the class which the following data can prove:

Table 3. The concentration of the students after using MMT

\begin{tabular}{ccc}
\hline Category & Respondent & Percentage \\
\hline Strongly disagree & 2 & $6.67 \%$ \\
\hline Disagree & 7 & $23.3 \%$ \\
\hline Strongly Agree & 4 & $13.33 \%$ \\
\hline Agree & 17 & $56.67 \%$ \\
\hline Total & 30 & $100 \%$ \\
\hline
\end{tabular}

Two students (6.67\%) were strongly disagree, seven students (23.3\%) were disagree, four students $(13.33 \%)$ were strongly agree, and seventeen students $(56.67 \%)$ were agree that they were easily to concentrate when using mind mapping technique. It is also supported with the classroom observation. Based on the observation, it was found that most of students did not focus in the class before using mind mapping technique. The distractions are varied, both from themselves or other students. Firstly, they could be bored, day-dreamed, and asleep when they were taught without using mind mapping technique. Secondly, they could not pay attention to the taught material when other students made a noise.

After using mind mapping technique, it was found that the students can listen well and pay attention to the explanation of materials and the atmosphere of the classroom became more conducive.

\subsection{The Effect of Mind Mapping Technique towards Students' Motivation in Learning Tenses}

The use of mind mapping technique could motivate the students to learn tenses based on the analysis of data. It can be proven from the classroom observation during the process of making mind mapping. There were several activities, such as making lines, making illustrations, and writing. All kinds of these activities stimulate students' thought and emotion, which evoked the spirit, interest, and enthusiasm of the students to learn tenses. Furthermore, it is also supported in the following data from questionnaire:

Table 4. The excitement of the students using MMT

\begin{tabular}{ccc}
\hline Category & Respondent & Percentage \\
\hline Strongly disagree & 0 & $0 \%$ \\
\hline Disagree & 6 & $20 \%$ \\
\hline Strongly Agree & 4 & $66.67 \%$ \\
\hline Agree & 20 & $13.33 \%$ \\
\hline Total & 30 & $100 \%$ \\
\hline
\end{tabular}


There was no student $(0 \%)$ who vehemently disagreed about being very excited in the use of mind mapping technique. Then, six students (20\%) were disagree, four students $(66.67 \%)$ were strongly agree, and twenty students (13.33\%) were agree that they were very excited when mind mapping technique was introduced to be used in teaching and learning process. It is also supported by interview data that most of the students were enjoyed the process of making mind mapping. It is because mind mapping facilitated them to learn the materials and enabled them to express their emotion through pictures and combination of colors in their mind map.

\subsection{The Effect of Mind Mapping Technique towards Students' Thinking Ability}

Mind mapping technique facilitates the students to remember and understand the material well based on the research. It can be seen from the classroom observation that the students created a basic idea in simple present tense and completed it with branches consisting of relevant supporting data.

For instance, the students were asked to make a mind map which the basic idea must be in simple present tense. Then, the related branches consist of the definition of simple present tense, the formula or pattern of simple present tense, and the use of simple present tense. Each branch must be completed with the symbols and keywords, so there will only a few words in the mind map. As the result, most students felt easy to remember the materials they learned and help them to finish the exercises well. The following data from questionnaire also supported the study:

Table 5. The understanding of the students towards the subject after using MMT

\begin{tabular}{ccc}
\hline Category & Respondent & Percentage \\
\hline Strongly disagree & 4 & $13.33 \%$ \\
\hline Disagree & 3 & $10 \%$ \\
\hline Strongly Agree & 6 & $56.67 \%$ \\
\hline Agree & 17 & $20 \%$ \\
\hline Total & 30 & $100 \%$ \\
\hline
\end{tabular}

Four students (13.33\%) were strongly disagree, three students (10\%) were disagree, six students $(56.67 \%)$ were strongly agree, and seventeen students $(20 \%)$ were agree that it was easier for them to understand the materials using mind mapping technique. In addition, the interview data also showed that most students feel easy to understand the materials using mind mapping technique because there are only a few words to be memorized. Therefore, the materials are easy to be remembered.

It is also found that making mind mapping can involve the relationship between the ideas and information in helping the students think synergistically. It is because the students can relate the things that they want to learn with the things they have already known. This statement is proven through the classroom observation that there were students who created a branch about the use of simple present tense from the main idea of simple present tense. The branch wrote the keyword "fact" as a meaning that the simple present tense is used to express a fact or general truth. The keyword "fact" is something that they want to know about the use of simple present tense. Then, they added a picture to support the keyword. The students drew about "the sun rises in the east" in which the students had known about the information of picture before. After that, they connected something they had known with something they wanted to know. Thus, they can easily remember it.

Table 6. Thinking speed of the students after using MMT

\begin{tabular}{ccc}
\hline Category & Respondent & Percentage \\
\hline Strongly disagree & 4 & $13.33 \%$ \\
\hline Disagree & 2 & $6.67 \%$ \\
\hline Strongly Agree & 18 & $60 \%$ \\
\hline Agree & 12 & $40 \%$ \\
\hline Total & 30 & $100 \%$
\end{tabular}

Four students (13.33\%) were strongly disagree, two students (6.67\%) were disagree, two students (60\%) were strongly agree, and twelve students (40\%) were agree that their thinking speed was increased after using mind mapping technique. Another effect of mind mapping technique towards thinking ability of the students is enabled them to think independently. From the observation, the students came up with their own ideas, looked out by themselves through the sources, and processed it into information in making mind mapping. In this process, the curiosity of the students was increased, especially when trying to connect one idea with another idea that they got from any sources. From this activity, 
it could bring up the students' curiosity to the learning materials. They also felt curious to find out and solve the problem. In addition, the data from questionnaire also complete the observation as follows:

Table 7. The improvement of students' curiosity after using MMT

\begin{tabular}{ccc}
\hline Category & Respondent & Percentage \\
\hline Strongly disagree & 4 & $13.33 \%$ \\
\hline Disagree & 9 & $30 \%$ \\
\hline Strongly Agree & 6 & $20 \%$ \\
\hline Agree & 11 & $36.67 \%$ \\
\hline Total & 30 & $100 \%$ \\
\hline
\end{tabular}

Four students $(13.33 \%)$ were strongly disagree, nine students $(30 \%)$ were disagree, six students $(20 \%)$ were strongly agree, and eleven students $(36.67 \%)$ were agree that mind mapping technique could improve the curiosity of the students.

\subsection{The Effect of Mind Mapping Technique towards Students' Creativity}

Mind mapping technique helps the students to release their imagination. Classroom observation can be proven that the students did not only instruct to write a summary of lessons, but also help them make mind mapping in the combination of colors, pictures, and branches connecting one idea and another idea. This activity could make the students to generate a variety of innovative ideas, thus their creativity could increase.

Based on the classroom observation, every student made their own mind mapping as attractive as possible and had different mind mapping by their imagination. Although there are some rules or instructions to follow, every student still has their own style and develops their own creativity in making mind mapping. It is also proven in the following questionnaire data:

Table 8. The students' creativity after using MMT

\begin{tabular}{ccc}
\hline Category & Respondent & Percentage \\
\hline Strongly disagree & 3 & $10 \%$ \\
\hline Disagree & 4 & $13.33 \%$ \\
\hline Strongly Agree & 13 & $43.34 \%$ \\
\hline Agree & 10 & $33.33 \%$ \\
\hline Total & 30 & $100 \%$ \\
\hline
\end{tabular}

Three students (10\%) were strongly disagree, four students (13.33\%) were disagree, thirteen students $(43.34 \%)$ were strongly agree, and ten students $(33.33 \%$ ) were agree that mind mapping technique helps the students to think creatively. In addition, based on the interview data, it was found that the students considered mind mapping technique developed their creativity because mind mapping technique did not only instruct to note or make a summary of lesson, but also express their imagination through drawing.

\subsection{The Effect of Mind Mapping Technique towards Time Management of the Students}

Mind mapping technique could make the time to be more efficient rather than using usual note-taking in reviewing the lesson. It can be proved from the interview that most students prefer to read and repeat the lessons. Mind mapping looks more eye-catching because it is colorful. They also think that mind mapping technique can make the time to be more efficient because there were only a few words to be read and remembered in compared to the usual note-taking.

Based on the observation, mind mapping technique also helped the students to learn particular topic quickly, remember the materials for a longer time, and finish the exercise quickly. It is because mind mapping technique provides clear, concise, and detailed information. Furthermore, it is also completed by the questionnaire data as follows:

Table 9. The time efficiency after using MMT

\begin{tabular}{ccc}
\hline Category & Respondent & Percentage \\
\hline Strongly disagree & 3 & $10 \%$ \\
\hline Disagree & 12 & $40 \%$ \\
\hline Strongly Agree & 3 & $10 \%$ \\
\hline Agree & 12 & $40 \%$ \\
\hline Total & 30 & $100 \%$
\end{tabular}


Three students (10\%) were strongly disagree, twelve students (40\%) were disagree, three students (10\%), were strongly agree, and twelve students $(40 \%)$ were agree that mind mapping technique could make the time to be more efficient.

\subsection{The Effect of Mind Mapping Technique towards Students' Communication Skills}

Regarding the students' communication ability, the effect of mind mapping technique made the students become more active to be involved in the teaching and learning process in the classroom.

It can be proved from the observation when using mind mapping technique. The students did more interaction in the classroom, such as asking the question, discussing with other students in group, and expressing their opinions and ideas. The students were easily to express their ideas that they got from their mind mapping.

It was also supported from the interview data that mind mapping technique made most students flexible in expressing the ideas systematically, thus they know exactly the ideas of their thought. Furthermore, the questionnaire data was also supported as follows:

Table 10. The effectiveness of MMT in explaining concepts

\begin{tabular}{ccc}
\hline Category & Respondent & Percentage \\
\hline Strongly disagree & 1 & $3.33 \%$ \\
\hline Disagree & 4 & $13.33 \%$ \\
\hline Strongly Agree & 8 & $26.67 \%$ \\
\hline Agree & 17 & $56.67 \%$ \\
\hline Total & 30 & $100 \%$
\end{tabular}

One student (3.33\%) was strongly disagree, four students (13.33\%) were disagree, eight students $(26.67 \%)$ were strongly agree, and seventeen students (56.67\%) were agree that the concept of materials are easily to be explained using mind mapping technique. Therefore, most students agreed that mind mapping technique helps teachers easily explain the concept of materials to them.

\subsection{Students' Perceptions on Mind Mapping Technique}

Based on the interview, it can be identified that most students had never experienced mind mapping technique in learning before. However, most students were interested to know when they were introduced to this technique. In addition, most students also considered that mind mapping technique was a good and efficient learning technique after they were taught the tenses material using this technique. It can be proved from the following questionnaire data:

Table 11. Perceptions after using MMT

\begin{tabular}{ccc}
\hline Category & Respondent & Percentage \\
\hline Strongly disagree & 0 & $0 \%$ \\
\hline Disagree & 3 & $10 \%$ \\
\hline Strongly Agree & 9 & $30 \%$ \\
\hline Agree & 18 & $60 \%$ \\
\hline Total & 30 & $100 \%$ \\
\hline
\end{tabular}

No student $(0 \%)$ strongly disagreed about mind mapping as a good learning technique. Then, three students $(10 \%)$ were disagree, nine students $(30 \%)$ were strongly agree, and eighteen students $(60 \%)$ were agree that mind mapping technique was a good learning technique.

It can also be proved from the observation that the students felt enthusiastic and excited when mind mapping technique was used in learning tenses. They considered that mind mapping technique could greatly help them to learn tenses. Furthermore, they also thought that mind mapping technique could bring a new atmosphere in the classroom which in turn increased their progress in learning. For instance, they could concentrate better on the materials being taught because the materials were easier to be understood.

Despite that, the result of observation also proved that the students were also actively responded to the teacher explanation and could explain their ideas in front of the class. Therefore, they were more active and not quickly bored to the teaching and learning process in the classroom. 
The interview data also showed that the students could easily remember the materials using mind mapping technique. It is because this technique used keywords, thus were only a few words to be memorized.

The students considered mind mapping technique to make them focus on expressing ideas about tenses material being learned and expressing their creativity through this technique, which in turn make them enjoyed the teaching and learning process.

However, there were also some students facing difficulties when mind mapping technique was used in learning tenses. It can be proved from the observation that some students were confused to make keywords and draw pictures related to the topic. It is because some students still wrote complete sentences and drew unrelated pictures about the topic. While, other students even did not draw any picture.

On the interview data, most students also found that they prefer to use mind mapping technique rather than usual note taking in learning tenses because this technique was not monotonous to be used. In addition, they also thought that they were more interested in reading their notes using this technique because it was colorful and full of pictures. It was therefore made them more often reading their notes. The following questionnaire data also supported this interview data:

Table 12. Perceptions towards the use of MMT and usual note taking

\begin{tabular}{ccc}
\hline Category & Respondent & Percentage \\
\hline Strongly disagree & 1 & $3.33 \%$ \\
\hline Disagree & 5 & $16.67 \%$ \\
\hline Strongly Agree & 16 & $26.67 \%$ \\
\hline Agree & 8 & $53.33 \%$ \\
\hline Total & 30 & $100 \%$ \\
\hline
\end{tabular}

One student (3.33\%) was strongly disagree, five students (16.67\%) were disagree, sixteen students $(26.67 \%)$ were strongly agree, and eight students $(53.33 \%)$ were agree that they preferred to use mind mapping technique rather than usual note taking. Furthermore, mind mapping technique was also considered easy to be used. It can be proved in the questionnaire data:

Table 13. Perceptions towards the practicality of using MMT

\begin{tabular}{ccc}
\hline Category & Respondent & Percentage \\
\hline Strongly disagree & 0 & $0 \%$ \\
\hline Disagree & 5 & $16.67 \%$ \\
\hline Strongly Agree & 7 & $23.33 \%$ \\
\hline Agree & 18 & $60 \%$ \\
\hline Total & 30 & $100 \%$ \\
\hline
\end{tabular}

There was no student $(0 \%)$ who strongly disagreed about using the mind mapping technique. Then, five students $(16.67 \%)$ were disagree, seven students $(23.33 \%)$ were strongly agree, and eighteen students $(60 \%)$ were agree that mind mapping technique was easy to be used. The students also found that mind mapping technique is an effective learning technique because they could finish the task quickly and made so much fun in learning activities.

\section{Conclusion}

Mind mapping technique can improve students' ability in learning tenses and the interest of students in the class. It helps the students in learning tenses because they were interested and enthusiastic in using this technique which in turn the atmosphere of the class become more enjoyable. The use of mind mapping technique is effective and can be considered an alternative technique in learning tenses. There was a significant result from the pre-test and post-test in which the mean score of the post-test was higher (78.92) than the mean score of the pre-test (42.33) after using this technique. Thus, the students' improvement score from the pre-test to the post-test was increased up to $86.44 \%$. Based on the results of the study, it is suggessted that further studies can be conducted with larger data to make it more accurate and applicable.

\section{References}

Aswad, M., et al (2019). A Software to Increase English Learning Outcomes: An Acceleration Model of English as the Second Language. The Asian EFL Journal 26 (6.2.2019), 157-169. 
Brown, H.D. 2001. Teaching by Principle: An Interactive Approach to Language Pedagogy. Longman, 2nd ed.

Buzan, Tony. 2013. Buku Pintar Mind Map. Jakarta: Gramedia Pustaka Utama.

Junaidi, J. (2020). ICT Usage in Teaching English in Pekanbaru: Exploring Junior High School Teachers' Problems. International Journal of Advanced Science and Technology 29 (3), 5052 - 5063

Nahliah, \& F Rahman, F. (2018). Glossophobia in Training of Speech. ELS Journal on Interdisciplinary Studies in Humanities 1 (1), 28-36

Olivia, Femi. 2013. 5-7 Menit Asyik Mind Maping Kreatif. Jakarta: Elex Media Komputindo.

Priyadisudiarja, Y., \& Purwaningsih, Y.S. 2014. Pintar Bahasa Inggris dengan Mind Map. Yogyakarta: Kawah Media.

Rahman, F. (2017). The Strategy of Teaching Literature Through Language-Based Method: A Communicative Approach. Annual Seminar on English Language Studies 2, 156-170

Rahman, F. (2018). The Constraints of Foreign Learners in Reading English Literary Works: A Case Study at Hasanuddin University. Journal of Arts \& Humanities (JAH) 7 (02, 2018), 01-12.

Riski, H., et al. (2018). Improving The Students'speaking Ability Through Silent Way Method At Smu Negeri 12 Makassar. JURNAL ILMU BUDAYA 6 (2), 303-312.

Windura, Sutanto. 2013. 1st Mind Map. Jakarta: Elex Media Komputindo.

Wishon, G.E \& Burks, J.M. 1980. Let's Write English. New York: American Book Company.

Junaidi, J., Hamuddin, B., Simangunsong, W., Rahman, F., \& Derin, T. (2020). ICT usage in teaching English in Pekanbaru: Exploring junior high school teachers' problems. International Journal of Advanced Science and Technology, 29(3), 5052-5063. 